\title{
Genetic diversity of Tibetan goats of Plateau type using microsatellite markers
}

\author{
Yong Wang', Jie Wang', Xiang-Dong Zi' ${ }^{2}$, Cai-Rang Huatai', Xi Ouyang' and Lu-Shu Liu' \\ 'Sichuan Provincial Key-Laboratory of Protection and Utilization of Animal Genetic Resources in Qinghai-Tibet Plateau, \\ ${ }^{2}$ Key Laboratory of Animal Genetics \& Breeding, State Ethnic Affairs Commission and Ministry of Education, Southwest \\ University for Nationalities, Chengdu, PR China
}

\section{Abstract}

The 10 microsatellite markers (XBM7, XBM11, XBM16, XBM19, XBM24, XBM31, XBM84, TGLA53, SRCRSP-10 and ILS005) were selected to investigate the genetic diversity of Tibetan goat of Plateau type (NM, $n=108)$, and the other 5 goat populations, i.e., Tibetan goat of Valley type (TG, $n=36)$, Baiyu black goat ( $B Y, n=36)$, Jianchang black goat (JC, $n=36$ ), Meigu goat ( $M G, n=36)$ and Xinjiang goat ( $X J, n=32$ ) were served as control. The mean polymorphism information content, heterozygosity and effective allele number of these 6 populations were 0.660/0.777/4.476,0.716/0.797/4.9416, 0.631/0.673/3.061,0.649/0.680/3.125, 0.629/0.680/3.125 and $0.561 / 0.793 / 4.840$ respectively. The allele frequencies of Tibetan goat of plateau type in 10 microsatellite loci were greatly different with other 5 goat populations. The 6 goat populations were grouped into three distinct clusters: the Tibetan goat cluster (NM goat and TG goat), Sichuan goat cluster (JC goat, MG goat and BY goat), and Xinjiang goat cluster (XJ goat). These 3 distinct clusters were finally clustered together. The genetic differences among populations were in accordance with their geographical and historical origins.

Keywords: Microsatellite DNA, genetic diversity, Tibetan goat

\section{Zusammenfassung}

\section{Genetische Diversität von Tibetischen Hochplateau-Ziegen unter Verwendung von Mikrosatellitenmarkern}

Die 10 Mikrosatellitenmarker (XBM7, XBM11, XBM16, XBM19, XBM24, XBM31, XBM84, TGLA53, SRCRSP-10 und ILS005) wurden ausgewählt, um die genetische Diversität von Tibetischen Hochplateau-Ziegen (NM, $\mathrm{n}=108)$ zu untersuchen, und die anderen 5 Ziegenpopulationen, d. h. Tibetische Tal-Ziege (TG, $n=36$ ) schwarze Baiyu-Ziege ( $B Y, n=36)$, schwarze JianchangZiege ( $J C, n=36)$, Meigu-Ziege ( $M G, n=36$ ) und Xinjiang-Ziege ( $X J, n=32)$ und Xinjian-Ziege $(\mathrm{XJ}, \mathrm{n}=32$ ) dienten als Kontrolle. Der durchschnittliche Polymorphismus-Informationsgehalt, die Heterozygosität und die effektive Allee-Anzahl dieser 6 Populationen betrugen $0,660 / 0,777 / 4,476,0,716 / 0,797 / 4,9416,0,631 / 0,673 / 3,061,0,649 / 0,680 / 3,125,0,629 / 0,680 / 3,125$ bzw. 0,561/0,793/4,840. Die Allelhäufigkeiten von Tibischen Hochplateau-Ziegen an 10 Mikrosatelliten-Loci unterscheiden sich sehr stark von den anderen 5 Populationen. Die 6 Ziegenpopulationen wurden in 3 distinkte Cluster gruppiert: das Cluster Tibetische Ziege (NM- und TG-Ziege), das Cluster Sichuan-Ziege (JC-, MG- und BY-Ziege) und das Cluster 
Xinjiang-Ziege (XJ-Ziege). Diese drei distinkten Cluster wurden schließlich miteinander verclustert. Die genetischen Unterschiede zwischen den Populationen standen mit ihrer geografischen und historischen Herkunft im Einklang.

Schlüsselwörter: Mikrosatelliten DNA, genetische Vielfalt, Tibetische Ziege

\section{Introduction}

The Tibetan goat is mainly distributed in Qinghai-Tibet plateau of China. It is regarded as one of the world's most remarkable domestic animals as it thrives in conditions of extreme harshness and deprivation while providing meat and down for people. The archaeological evidence from Kaluo ruin in Changdu of Tibet suggests that the history of China's Tibetan goat industry is at least 4000 years old (Wang et al. 1993). At the present time, the total Tibetan goat population is estimated to number around 18 million in China. They were classified as plateau type and valley type (Ouyang et al. 1995). Tibetan goats are famous for their down production and good quality. In fact, what was called Cashmere goat by British businessmen in international cashmere trade during 1770s is Tibetan goat (Wang et al. 1994). There is, however, little study have been undertaken to investigate the genetic characteristics of Tibetan goat using molecular biological techniques. Microsatellites have been commonly utilized for the assessment of genetic diversity, construction of genetic maps, quantitative trait loci mapping and parentage testing etc. (Batendse et al. 1997, Buchanan et al. 1994, Li et al. 2004, Wang et al. 2004, Jin et al. 2005, Agha et al. 2008, Manatrinon et al. 2008, Ślaska et al. 2008, Kusza et al. 2010). Li et al. (2002) analyzed genetic relationships among twelve Chinese indigenous goat populations based on 26 microsatellite markers. Wang et al. (2006) studied microsatellite DNA polymorphism of 9 breeds (populations) of black goats in Sichuan province using 10 microsatellite markers, and the result showed these 9 breeds (populations) have a high genetic diversity. This observation is consistent with population's bodily form, economical purpose and geographical distributions. There is, however, no information is available for genetic diversity of Tibetan goat of plateau type by using microsatellites markers.

Therefore, the objective of this study was to analyze genetic diversity of Tibetan goat by using 10 microsatellite loci. The results would be useful for the protection and utilization of Tibetan goat genetic resources in China.

\section{Materials and methods}

\section{Sampling and DNA extraction}

Genomic DNAs were prepared from whole blood, which were collected from female goats of six populations: plateau-type Tibetan goats in Nima county of Tibetan Autonomous Region (NM, $n=108$ ), valley-type Tibetan goats in Mao county of Sichuan province ( $T G, n=36)$, Baiyu goats in Baiyu county of Sichuan (BY, $n=36$ ), Jianchang black goats in Huili county of Sichuan $(J C, n=36)$, Meigu goats in Meigu county of Sichuan ( $M G, n=36$ ), and Xinjiang goats in Changji city of Xinjiang Region (XJ, $n=32$ ). All breeds were kept at their own origin area. Individuals from each breed were sampled with the proportion of male:female equaling 1:4, according to Barker's (1994) guidelines for sample requirements of genetic diversity evaluation. Owners 
were questioned in detail to minimize the sampling of closely related individuals. The original and distribution of these six populations were shown in Figure 1. Genomic DNAs from samples were extracted according to procedures described by Wang et al. (2006).

\section{$P C R$ and microsatellite analysis}

Ten pairs of microsatellite primers used were synthesized (TakaRa, Dalian, China) and their sequences were shown in Table 1. PCR was accomplished in a total $15 \mu \mathrm{l}$ of the following mixture: $25 \mathrm{ng} / \mu \mathrm{l}$ of genomic DNA, $20 \mathrm{pmol} / \mathrm{l}$ of each primers, $2 \mathrm{U}$ ExTaq DNA polymerase, $100 \mu \mathrm{mol} / \mathrm{l}$ of each dNTPs, standard PCR buffer, $2 \mathrm{mmol} / / \mathrm{MgCl}_{2}$ and dd $\mathrm{H}_{2} \mathrm{O}$. PCR amplification was as follows: first step was performed by initial denaturation for 4 min at $94^{\circ} \mathrm{C}$, followed by 33 cycles at $94^{\circ} \mathrm{C}$ for $40 \mathrm{~s}, 54-59^{\circ} \mathrm{C}$ for $40 \mathrm{~s}$ and $72^{\circ} \mathrm{C}$ for $1 \mathrm{~min}$. An extension at $72^{\circ} \mathrm{C}$ for $5 \mathrm{~min}$. PCR products were stored at $4^{\circ} \mathrm{C}$. Amplified fragments were analyzed on $9 \%$ polyacrylamide denaturing sequencing gel which was stained in $0.1 \% \mathrm{AgNO}_{3}$ solution. The PCR product size was calculated according to the pBR322 DNA/mspl marker on the computer.

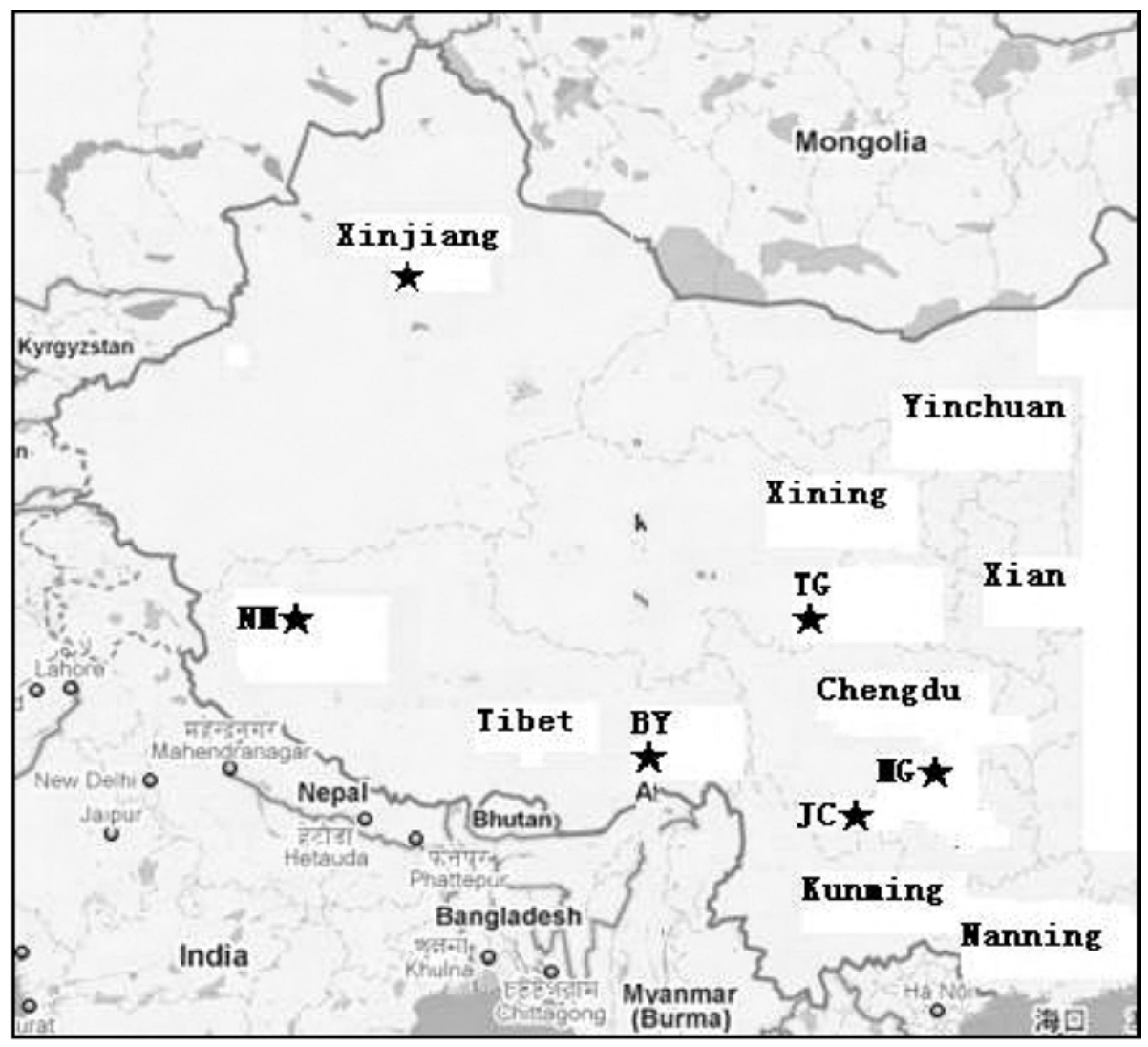

Figure 1

The geographic location of each of 6 populations of goats 
Table 1

The sequence structure of the 10 microsatellite primer pairs

\begin{tabular}{lll}
\hline Loci & Forward 5`3` & Reverse 5`-3` \\
\hline XBM7 & CTG TAT TAG AGT TCC CTG GAG AAA & GCC AAC ATG CCC TGT AGA AT \\
XBM11 & TAC TGA TGG GAG GTT TCT GAG A & CCC AGA GTC TTT GTG TCA AGG \\
XBM16 & AGG ATA ATT TGC TCT GTG CCC & ATG GCA ATA TGA GGA GTT GC \\
XBM19 & AAG AAT CGG ACA TGA CTG AAT G & CCT CCT TCA TAA TCC ATT AAG CT \\
XBM24 & TTA CCA CTG AGC CAC CTG G & ATG ATG CTT CTG TCA AGA GGT T \\
XBM31 & GAT CCA ACG GAT GTT AGC AA & GCC ACA CAG TCA AAT GAA TCA \\
XBM84 & TCA GGT GAA TAC TTT CCC ACG & TCC TTG TGT CCC TTT AGT TTT G \\
TGLA53 & CAG CAG ACA GCT GCA AGA GTT AGC & CTT TCA GAA ATA GTT TGC ATT CAT GCA G \\
SRCRSP-10 & ACC AGT TTG AGT ATC TTG CTT GGG & AGG AAG TTT ATT GGA CAG TGC TGG \\
ILS005 & GGA AGC AAT GAA ATC TAT AGC C & TGT TCT GTG AGT TTG TAA GC \\
\hline
\end{tabular}

\section{Statistical analysis}

Allele frequencies, polymorphism information content (PIC) (May et al. 1995), heterozygosity (H) (Heam et al. 1992), effective allele number (Ne) (Kimura \& Crow 1974, Hines et al. 1981). The dendrogram was constructed by using UPGMA method from the calculated Nei's standard genetic distance (Da) (Nei 1978).

\section{Results}

\section{Number of alleles and allele frequencies}

Genotypes were observed according to the size of amplified fragments (a, b, c.....): a single band indicated homozygote; two bands indicated heterozygote (Figure 2). If SSR primers gave no amplified product were treated as missing values and they were discarded in the following study. The allele number and frequencies of 10 microsatellite loci in the 6 goat populations were shown in Table 2. The number of alleles per locus ranged from 3 (XBM31) to 8 (XBM16) with an average value of 5.7 in NM plateau type Tibetan goat. According to standard selection of microsatellite loci (Barker 1994), it has been suggested that microsatellite ought to have at least 4 alleles to be useful for the evaluation of genetic diversity, however, 3 alleles per locus were also used to evaluate genetic diversity in some studies (Li et al. 2010), therefore, all 10 microsatellites were used in this study.

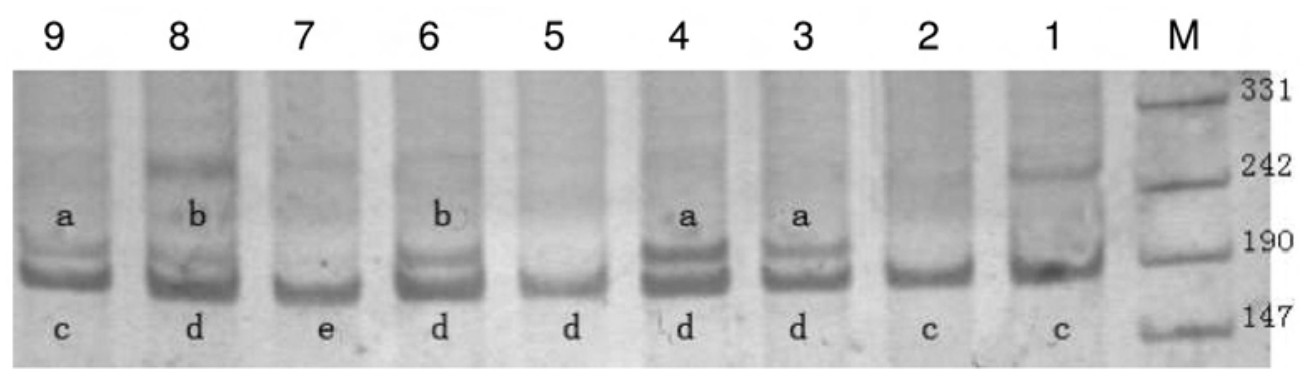

Figure 2

Electrophoresis photograph of locus ILS005 in NM Tibetan goat population 
There was a great difference in allele frequencies and genotype frequencies among different populations. For example, allele $\mathrm{h}$ (XBM16) was only observed in NM goat and TG goat with frequency of 0.017 where not observed in other breeds analyzed (BY goat, JC goat, MG goat and XJ goat). Allele $a$ and b (ILS005 and XBM24) were not observed in XJ goat, but allele $\mathrm{g}$ (ILS005 and XBM24) was only observed in this population with frequency of 0.317 and 0.383 , respectively. Allele $\mathrm{f}$ (XBM7) was only detected in NM goat, TG goat and XJ goat with frequency of $0.250,0.250$ and 0.333 , respectively.

Table 2

Allele frequencies of 10 microsatellite loci in the 6 goat breeds (populations)

\begin{tabular}{|c|c|c|c|c|c|c|c|c|c|c|c|c|c|}
\hline $\begin{array}{l}\text { Locus } \\
\text { allele }\end{array}$ & NM & TG & BY & $J C$ & MG & XJ & $\begin{array}{l}\text { Locus } \\
\text { allele }\end{array}$ & NM & TG & BY & $J C$ & MG & XJ \\
\hline ILS005 & & & & & & & XBM24 & & & & & & \\
\hline$a$ & 0.167 & 0.083 & 0.150 & 0.217 & 0.133 & 0.000 & $a$ & 0.200 & 0.183 & 0.267 & 0.217 & 0.250 & 0.000 \\
\hline b & 0.000 & 0.167 & 0.067 & 0.050 & 0.050 & 0.000 & $\mathrm{~b}$ & 0.117 & 0.150 & 0.350 & 0.350 & 0.350 & 0.000 \\
\hline c & 0.150 & 0.117 & 0.217 & 0.250 & 0.250 & 0.133 & C & 0.150 & 0.150 & 0.083 & 0.067 & 0.067 & 0.000 \\
\hline$d$ & 0.200 & 0.167 & 0.217 & 0.200 & 0.283 & 0.233 & $d$ & 0.300 & 0.250 & 0.300 & 0.233 & 0.183 & 0.000 \\
\hline e & 0.283 & 0.267 & 0.167 & 0.233 & 0.250 & 0.000 & e & 0.233 & 0.150 & 0.000 & 0.133 & 0.150 & 0.317 \\
\hline$f$ & 0.200 & 0.200 & 0.183 & 0.050 & 0.033 & 0.317 & $f$ & 0.000 & 0.117 & 0.000 & 0.000 & 0.000 & 0.300 \\
\hline $\begin{array}{l}\text { g } \\
\text { XBM7 }\end{array}$ & 0.000 & 0.000 & 0.000 & 0.000 & 0.000 & 0.317 & $\begin{array}{l}\mathrm{g} \\
\mathrm{XBM} 84\end{array}$ & 0.000 & 0.000 & 0.000 & 0.000 & 0.000 & 0.383 \\
\hline $\mathrm{a}$ & 0.000 & 0.083 & 0.200 & 0.217 & 0.217 & 0.000 & $\mathrm{a}$ & 0.1 & 0.117 & 0.233 & 0.233 & 0.233 & 0.000 \\
\hline b & 0.033 & 0.000 & 0.217 & 0.217 & 0.217 & 0.000 & $\mathrm{~b}$ & 0.483 & 0.417 & 0.317 & 0.283 & 0.333 & 0.317 \\
\hline c & 0.283 & 0.267 & 0.367 & 0.367 & 0.417 & 0.200 & C & 0.417 & 0.25 & 0.133 & 0.133 & 0.133 & 0.300 \\
\hline$d$ & 0.233 & 0.200 & 0.217 & 0.033 & 0.150 & 0.233 & $d$ & 0.000 & 0.117 & 0.2 & 0.183 & 0.283 & 0.383 \\
\hline e & 0.200 & 0.200 & 0.000 & 0.167 & 0.000 & 0.233 & e & 0.000 & 0.100 & 0.117 & 0.167 & 0.017 & 0.000 \\
\hline$f$ & 0.250 & 0.250 & 0.000 & 0.000 & 0.000 & 0.333 & & & & & & & \\
\hline SRCR-10 & & & & & & & XВM19 & & & & & & \\
\hline a & 0.183 & 0.167 & 0.267 & 0.233 & 0.383 & 0.367 & $a$ & 0.033 & 0.100 & 0.467 & 0.450 & 0.350 & 0.000 \\
\hline$b$ & 0.200 & 0.183 & 0.267 & 0.300 & 0.050 & 0.000 & $b$ & 0.217 & 0.200 & 0.483 & 0.400 & 0.500 & 0.000 \\
\hline c & 0.300 & 0.300 & 0.233 & 0.317 & 0.450 & 0.633 & C & 0.400 & 0.367 & 0.050 & 0.150 & 0.150 & 0.500 \\
\hline$d$ & 0.317 & 0.217 & 0.067 & 0.083 & 0.050 & 0.000 & $d$ & 0.350 & 0.333 & 0.000 & 0.000 & 0.000 & 0.500 \\
\hline e & 0.000 & 0.133 & 0.167 & 0.067 & 0.067 & 0.000 & & & & & & & \\
\hline XBM11 & & & & & & & ХВМ31 & & & & & & \\
\hline $\mathrm{a}$ & 0.083 & 0.183 & 0.450 & 0.350 & 0.300 & 0.317 & $\mathrm{a}$ & 0.233 & 0.167 & 0.000 & 0.000 & 0.000 & 0.467 \\
\hline b & 0.200 & 0.217 & 0.000 & 0.000 & 0.000 & 0.217 & $\mathrm{~b}$ & 0.317 & 0.417 & 0.583 & 0.536 & 0.550 & 0.533 \\
\hline c & 0.250 & 0.183 & 0.433 & 0.533 & 0.600 & 0.467 & C & 0.450 & 0.417 & 0.417 & 0.467 & 0.450 & 0.000 \\
\hline$d$ & 0.467 & 0.417 & 0.117 & 0.117 & 0.100 & 0.000 & & & & & & & \\
\hline XBM16 & & & & & & & TGLA & & & & & & \\
\hline $\mathrm{a}$ & 0.000 & 0.133 & 0.150 & 0.117 & 0.183 & 0.167 & $\mathrm{a}$ & 0.150 & 0.100 & 0.000 & 0.067 & 0.067 & 0.000 \\
\hline b & 0.000 & 0.000 & 0.383 & 0.400 & 0.267 & 0.000 & $b$ & 0.167 & 0.150 & 0.017 & 0.067 & 0.067 & 0.000 \\
\hline c & 0.000 & 0.000 & 0.400 & 0.267 & 0.267 & 0.000 & C & 0.100 & 0.067 & 0.250 & 0.050 & 0.050 & 0.000 \\
\hline$d$ & 0.300 & 0.233 & 0.000 & 0.150 & 0.167 & 0.000 & $d$ & 0.150 & 0.133 & 0.100 & 0.050 & 0.083 & 0.267 \\
\hline e & 0.333 & 0.300 & 0.000 & 0.000 & 0.000 & 0.300 & $\mathrm{e}$ & 0.233 & 0.167 & 0.233 & 0.350 & 0.283 & 0.233 \\
\hline$f$ & 0.350 & 0.317 & 0.067 & 0.067 & 0.117 & 0.267 & $f$ & 0.200 & 0.150 & 0.067 & 0.083 & 0.083 & 0.250 \\
\hline g & 0.000 & 0.000 & 0.000 & 0.000 & 0.000 & 0.267 & $\mathrm{~g}$ & 0.000 & 0.133 & 0.167 & 0.167 & 0.200 & 0.250 \\
\hline $\mathrm{h}$ & 0.017 & 0.017 & 0.000 & 0.000 & 0.000 & 0.000 & $\mathrm{~h}$ & 0.000 & 0.100 & 0.167 & 0.167 & 0.167 & 0.000 \\
\hline
\end{tabular}

Polymorphism information content (PIC), heterozygosity ( $\mathrm{H}$ ) and effective allele number ( $\mathrm{Ne}$ )

The PIC, $\mathrm{H}$ and $\mathrm{Ne}$ of 10 microsatellite loci in six goat populations were shown in Table 3. The PIC ranged from 0.832 (TGLA53) to 0.526 (XBM31). The PIC in 10 microsatellite loci was higher than 0.5 , indicated that the genetic diversity was abundant. The PIC was higher in 
NM goat (0.660) and TG goat (0.716) than BY goat (0.631), GC goat (0.649), MG goat (0.629) and $\mathrm{XJ}$ goat $(0.561)$.

The mean of heterozygosity of the six goat populations in 10 microsatellite loci was 0.733 ranged from 0.822 (XBM24 and TGLA53) to 0.617 (XBM11), revealed abundant polymorphism in these 10 microsatellite loci. Among populations, the mean of heterozygosity was low in MG goat (0.680), JC goat (0.680) and BY goat (0.673). However, NM goat and TG goat had a high heterozygosity, 0.777 and 0.797 respectively, which is greater than the expected heterozygosity ( 0.726 and 0.770 , respectively). These observations indicated NM goat and TG goat were greatly different from MG goat, JC goat and BY goat in the genetic diversity.

Table 3

Polymorphism information content (PIC), heterozygosity $(\mathrm{H})$ and effective allele number (Ne) of 10 microsatellite loci in 6 goat breeds (populations)

\begin{tabular}{|c|c|c|c|c|c|c|c|c|}
\hline Locus & Parameters & NM & TG & BY & JC & MG & XJ & Mean \\
\hline \multirow[t]{3}{*}{ ILS005 } & PIC & 0.756 & 0.786 & 0.791 & 0.758 & 0.737 & 0.676 & 0.807 \\
\hline & $\mathrm{H}$ & 0.700 & 0.733 & 0.733 & 0.633 & 0.633 & 0.767 & 0.700 \\
\hline & $\mathrm{Ne}$ & 3.333 & 3.745 & 3.745 & 2.725 & 2.725 & 4.292 & 3.428 \\
\hline \multirow{3}{*}{ XBM7 } & PIC & 0.720 & 0.743 & 0.684 & 0.700 & 0.661 & 0.692 & 0.777 \\
\hline & $\mathrm{H}$ & 0.733 & 0.733 & 0.600 & 0.667 & 0.567 & 0.767 & 0.678 \\
\hline & $\mathrm{Ne}$ & 3.745 & 3.745 & 2.500 & 3.003 & 2.309 & 4.292 & 3.266 \\
\hline \multirow[t]{3}{*}{ SRCRSP-10 } & PIC & 0.687 & 0.750 & 0.733 & 0.699 & 0.575 & 0.357 & 0.701 \\
\hline & $\mathrm{H}$ & 0.700 & 0.733 & 0.667 & 0.700 & 0.700 & 0.667 & 0.694 \\
\hline & $\mathrm{Ne}$ & 3.333 & 3.745 & 3.003 & 3.333 & 3.333 & 3.003 & 3.292 \\
\hline \multirow[t]{3}{*}{ XBM11 } & PIC & 0.619 & 0.664 & 0.509 & 0.499 & 0.466 & 0.561 & 0.647 \\
\hline & $\mathrm{H}$ & 0.700 & 0.733 & 0.467 & 0.500 & 0.533 & 0.767 & 0.617 \\
\hline & $\mathrm{Ne}$ & 3.333 & 3.745 & 1.876 & 2.000 & 2.141 & 4.292 & 2.808 \\
\hline \multirow[t]{3}{*}{ XBM16 } & PIC & 0.607 & 0.690 & 0.602 & 0.686 & 0.748 & 0.691 & 0.824 \\
\hline & $\mathrm{H}$ & 0.733 & 0.767 & 0.633 & 0.767 & 0.833 & 0.833 & 0.761 \\
\hline & $\mathrm{Ne}$ & 3.745 & 4.292 & 2.725 & 4.292 & 5.988 & 5.988 & 4.505 \\
\hline \multirow[t]{3}{*}{ XBM19 } & PIC & 0.603 & 0.649 & 0.442 & 0.534 & 0.527 & 0.375 & 0.696 \\
\hline & $\mathrm{H}$ & 0.767 & 0.800 & 0.667 & 0.667 & 0.667 & 0.800 & 0.728 \\
\hline & $\mathrm{Ne}$ & 4.292 & 5.000 & 3.003 & 3.003 & 3.003 & 5.000 & 3.884 \\
\hline \multirow[t]{3}{*}{ XBM24 } & PIC & 0.744 & 0.798 & 0.653 & 0.714 & 0.715 & 0.589 & 0.807 \\
\hline & $\mathrm{H}$ & 0.833 & 0.867 & 0.833 & 0.833 & 0.800 & 0.767 & 0.822 \\
\hline & $\mathrm{Ne}$ & 5.988 & 7.519 & 5.988 & 5.988 & 5.000 & 4.292 & 5.623 \\
\hline \multirow[t]{3}{*}{ XBM31 } & PIC & 0.569 & 0.545 & 0.368 & 0.374 & 0.372 & 0.374 & 0.526 \\
\hline & $\mathrm{H}$ & 0.833 & 0.800 & 0.700 & 0.667 & 0.767 & 0.800 & 0.761 \\
\hline & $\mathrm{Ne}$ & 5.988 & 7.519 & 5.988 & 5.988 & 5.000 & 4.292 & 5.796 \\
\hline \multirow[t]{3}{*}{ TGLA53 } & PIC & 0.798 & 0.852 & 0.786 & 0.778 & 0.806 & 0.702 & 0.833 \\
\hline & $\mathrm{H}$ & 0.900 & 0.933 & 0.800 & 0.733 & 0.733 & 0.833 & 0.822 \\
\hline & $\mathrm{Ne}$ & 10.000 & 14.925 & 5.000 & 3.745 & 3.745 & 5.988 & 7.234 \\
\hline \multirow[t]{3}{*}{ XBM84 } & PIC & 0.494 & 0.686 & 0.738 & 0.752 & 0.689 & 0.589 & 0.715 \\
\hline & $\mathrm{H}$ & 0.867 & 0.867 & 0.633 & 0.633 & 0.567 & 0.933 & 0.750 \\
\hline & $\mathrm{Ne}$ & 7.519 & 7.519 & 2.725 & 2.725 & 2.309 & 14.925 & 6.287 \\
\hline \multirow[t]{3}{*}{ Mean } & PIC & 0.660 & 0.716 & 0.631 & 0.649 & 0.629 & 0.561 & 0.733 \\
\hline & $\mathrm{H}$ & 0.777 & 0.797 & 0.673 & 0.680 & 0.680 & 0.793 & 0.733 \\
\hline & $\mathrm{Ne}$ & 5.128 & 6.175 & 3.655 & 3.680 & 3.555 & 5.636 & 4.639 \\
\hline
\end{tabular}


The mean effective number of alleles per locus was 4.476 in NM goat, ranged from 3.333 (ILS005, SRCRSP-10, XBM11 to 10.000 (TGLA53). Among the different populations, TG goat had the highest mean effective number of alleles (4.916) ranged from 3.745 (ILS005, XBM 7, SRCRSP-10, XBM11) to 14.925 (TGLA53). BY goat had the lowest mean effective number of alleles (3.061) ranged from 1.876 (XBM11) to 5.988 (XBM24, XBM31). The mean effective number of alleles in 10 microsatellite loci was 3.750 ranged from 3.061 (BY goat) to 4.916 (TG goat), and the mean effective number of alleles per locus ranged from 2.609 (XBM11) to 5.623 (XBM24). These results indicated that the 10 microsatellite loci of these 6 goat populations had abundant genetic diversity.

\section{Genetic distances and population relationship}

Estimates of the Da genetic distances among the 6 populations were shown in Table 4. The smallest Da distances were observed between JC goat and MG goat (0.063), and the largest Da distances between BY goat and XJ goat. Using UPGMA cluster method, the dendrogram of relationships among these six goat populations was obtained (Figure 3). The NM goat and TG goat populations were grouped together. JC goat, MG goat and BY goat populations were grouped together, but the XJ goat has separate branch. These three distinct groups were finally clustered together.

Table 4

Nei's standard genetic distances ( $\mathrm{Da}$ ) below the diagonal and standard errors above the diagonal between NM and other 5 goat populations

\begin{tabular}{lcccccc}
\hline Populations & NM & TG & BY & JC & MG & XJ \\
\hline NM & & 0.008 & 0.133 & 0.106 & 0.085 & 0.086 \\
TG & 0.063 & & 0.112 & 0.866 & 0.068 & 0.074 \\
BY & 0.318 & 0.235 & & 0.009 & 0.017 & 0.216 \\
JC & 0.261 & 0.194 & 0.043 & & 0.013 & 0.172 \\
MG & 0.266 & 0.200 & 0.042 & 0.026 & & 0.166 \\
XJ & 0.311 & 0.270 & 0.464 & 0.435 & 0.404 & \\
\hline
\end{tabular}

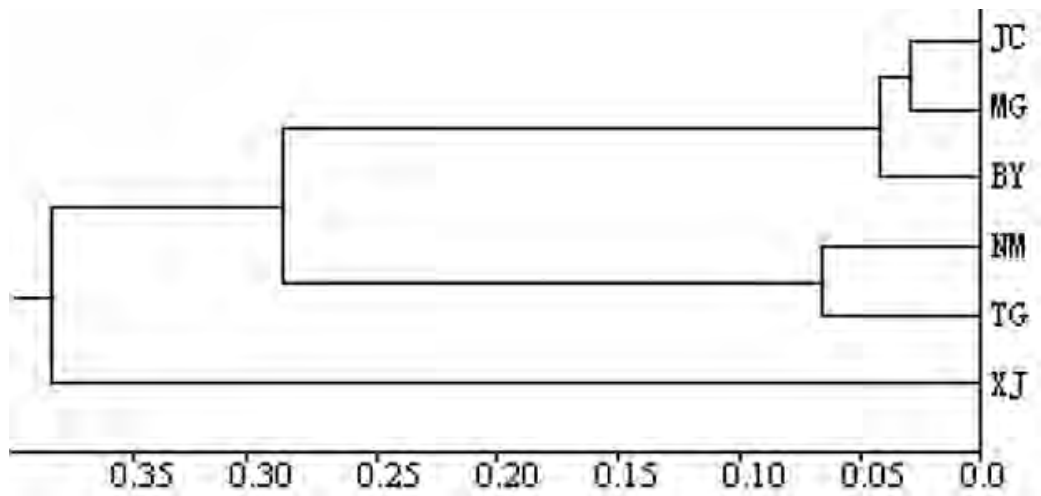

Figure 3

The UPMG dendrogram showing the genetic relationship among 6 goat populations using Nei's standard genetic distance for 10 microsatellite loci. 


\section{Discussion}

\section{Genetic diversity within populations}

The level of mean population heterozygosity reflects the degree of population genetic consistency. The lower is the population heterozygosity, the higher is the population genetic consistency and vice versa (Barker 1994). The present work showed that plateau type Tibetan goat and the other five goat population had a high heterozygosity in 10 microsatellite loci within population with an average of 0.733 ranged from 0.673 (BY goat) to 0.797 (TG goat) (Table 3). These results showed abundant polymorphism of these populations, i.e., a small effort for breeding has been performed in these populations, providing a possible reason for the high degree of genetic diversity in these populations. The effective number of alleles is an estimate of the number of alleles with equal frequencies corresponding to a particular PIC value. It is an inverse function of the theoretical homozygosity and it allows comparison of populations with different distributions of allele frequencies, reducing the effect of infrequent alleles (Barker 1994, Jin et al. 2005). The mean effective allele numbers were highest in XJ goat (4.840) and lowest in NM Tibetan goat (4.476) in this study.

Morin et al. (1994) reported that the polymorphism of microsatellite loci can reflect the evolution history of populations. The alleles with the highest frequency within a population are the most original and conservative, and the other alleles are originated from them during evolution by mutation. Accordingly, allele $c$ and e (ILS005), d (XBM7), c (SRCRSP-10, XBM11), $d$ (XBM24), b (XBM31, XBM84) and e (TGLA53) were the original alleles of these microsatellite loci in these goat populations. Some alleles observed or not observed in other microsatellite loci within goat populations should be as a result of evolution or mutation. These loci can be used as candidate microsatellite markers for studying population characteristics.

\section{Genetic relationship analysis between populations}

The allele frequencies were greatly different in different populations. In addition, some alleles were only detected in some populations, for example, allele $\mathrm{h}$ (XBM16) was only observed in Tibetan goats (both NM goat and TG goat) with frequency of 0.017; $a$ and b (ILS005 and XBM24) were not observed in XJ goat, but $g$ was only observed in this population with the frequency of 0.317 and 0.383 . These variations might be related to the genetics and variation, evolution, selection and ecological conditions (Chen \& Ma 2001, Li et al. 2002).

The mean polymorphism information was an ideal index to measure the polymorphism of allele fragments. PIC $>0.5$, indicated the locus of high-polymorphism; $0.25<\mathrm{PIC}<0.5$, indicated the locus of medium- polymorphism; PIC $<0.25$, indicated the locus of low-polymorphism (Cho 2006, Wang et al. 2006). In the present study, PIC of Tibetan goat of plateau type (0.660) and valley type (0.716) were higher than the other four goat populations, but the PIC of other 4 populations were also higher than 0.5 ranged from 0.561 to 0.649 . These results indicated that genetic information was also abundant in these populations.

The 6 goat populations are grouped into three distinct clusters: the Tibetan goat cluster (NM goat and TG goat), Sichuan goat cluster (JC goat, MG goat and BY goat) and Xinjiang goat cluster (XJ goat). These three distinct groups are finally clustered together. These clustering results were in accordance with their geographical and historical origins of these 6 
populations (Zheng 1989, Sun 1997). TG goat is distributed in Sichuan, but its historical origin is Tibetan goat. In contrast, BY goat is distributed in Baiyu county, Qinghai-Tibet Plateau, but its historical origin is not Tibetan goat (Figure 1 and 3). Although genetic diversity was not studied in these goat populations by molecular biological methods, evidences in chicken and pigs obtained by microsatellite markers (Chen et al. 1991, Wang et al. 2004) are consistent with those by blood protein markers and mtDNA diversity (Chen et al. 1991, Huang et al. 1998, Mo et al. 2003).

In conclusion, Tibetan goat of plateau type has abundant genetic diversity. It is a unique gene pool, developed for a long history by natural selection and artificial selection, with a good adaptation to the extremely cold and low oxygen conditions. The results would be useful for the protection and utilization of Tibetan goat genetic resources in China.

\section{Acknowledgements}

The work was supported by grants from Science and Technology Bureau of Sichuan Province (Project No. 2008JY0067-1), PR China.

\section{References}

Agha SH, Pilla F, Galal S, Shaat I, Andrea MD, Reale S, Abdelsalam AZA, Li MH (2008) Genetic diversity in Egyptian and Italian goat breeds measured with microsatellite polymorphism. J Anim Breed Genet 125, 194-200

Barker JSF (1994) A global protocol for determining genetic distances among domestic livestock breeds. Proc 5th World Cong Genet Appl Livest Prod, Guelph, Canada, 21, 501-508

Batendse W, Vaiman D, Kemp SL (1997) A medium density genetic linkage map of the bovine genome. Mammalian Genome 8, 21-28

Buchanan FC, Adams LJ, Litllejohn PR, Maddox JF, Crawford AM (1994) Determination of evolutionary relationships among sheep breeds using microsatellites. Genomic 22, 397-403

Chen GC, Zhou DW, Wu LC (1991) Chicken blood studies. Acta Gene 18, 415-423

Chen NZ, Ma KP (2001) Genetic Diversity - Principles and Practice. Shanghai: Shanghai Science and Technology Press. 90-96 [in Chinese]

Cho GJ (2006) Genetic relationship among the Korean native and alien horses estimated by microsatellite polymorphism. Asian-Aust J Anim Sci 19, 784-788

Heam CM, Ghosh S, Todd JA (1992) Microsatellites for linkage analysis of genetic traits. Trends in Genetics 8, 288-294

Hines HC, Zikakis JP, Haenlein GF, Kiddy CG, Trowbridge CL (1981) Linkage relationships among loci of polymorphisms in blood and milk of cattle. J Dairy Sci 64, 71-76

Huang YF, Zhang YP, Qiu XP, Zeng FT, Xiao YZ (1998) Relationship between the mtDNA polymorphism of pigs and the evolutionary divergence of Chinese indigenous pig breeds. Acta Genetica Sinica 25, 322-329

Jin HG, Zhao YM, Zhou GL (2005) Analysis of microsatellite DNA polymorphisms in five China native cattle breeds and application to population genetics studies. Asian-Aust J Anim Sci 18, 1696-1700

Kimura M, Crow JF (1994). The number of alleles that can be maintained in a finite population. Genetics 49, 725-738

Kusza S, Nagy I, Németh T, Molnár A, Jávor A, Kukovics S (2010) The genetic variability of Hungarian Tsigai sheep. Arch Tierz 53, 309-317

Li C, Wang Z, Liu B, Yang S, Zhu Z, Fan B, Yu M, Zhao S, Li K (2004) Evaluation of the genetic relationship among 
ten Chinese indigenous pig breeds with twenty-six microsatellite markers. Asian-Aust J Anim Sci 17, 441444

Li HF, Song WT, Shu JT, Chen KW, Zhu WQ, Han W, Xu WJ (2010) Genetic diversity and population structure of 10 Chinese indigenous egg-type duck breeds assessed by microsatellite polymorphism. J Genet 89, 65-72

Li MH, Zhao SH, Bian C, Wang HS, Wei H, Liu B, Yu M, Fan B, Chen SL, Zhu ML, Li SJ, Xiong TA, Li K (2002) Genetic relationship among twelve Chinese indigenous goat populations based on microsatellite analysis. Genet Sel Evol 34, 729-744

Littlejohn RP, Maddox JF, Crawford AM (1994) Determination of evolutionary relationships among sheep breeds using microsatellites. Genomics 22, 397-403

Manatrinon S, Fischerleitner F, Baumung R (2008) Genetic characterization among some Austrian and Hungarian cattle breeds. Arch Tierz 51, 426-437

May B, Krueger CC, Eng C, Paul E (1995) Genes in Populations, Version 2.0: A Computer Program for Analysis of Genetic Data, Cornell Laboratory for Ecological and Evolutionary Genetics, Cornell Univ, Ithaca, New York

Mo DL, Liu B, Wang ZG, Zhao SH, Yu M, Li K (2003) Genetic variation and genetic relationship of seventeen Chinese indigenous pig breeds using ten serum protein loci. Asian-Aust J Anim Sci 16, 939-945

Morin PA, Moore JJ, Chakraborty R, Jin L, Goodall J, Woodruff DS (1994) Kin selection, social structure, gene flow, and the evolution of chimpanzees. Science 265, 1193-1201

Nei M (1978) Estimation of average heterozygosity and genetic distance from a small number of individuals. Genetics 89, 583-590

Ouyang X, Wang J, Wang Y, Zhong Y (1995) Ecogeographic distributions and ecotypes of Tibetan goats. J Southwest University for Nationalities (Natural Science Edition) 6, 264-271 [in Chinese, English abstract]

Ślaska B, Jeżewska G, Zięba G, Pierzchała M (2008) Genetic variability and linkage of selected microsatellite markers in the Chinese raccoon dog (Nyctereutes procyonoides procyonoides). Arch Tierz 51, 187-198

Sun JM (1997) Origin and evolution of goats. Chinese J Rabbit Farming 1, 6-8

Wang J, Chen MH, Huatai CR, Ouyang X, Wang Y, Fu CX, Zhou GM (2006) Polymorphism research of microsatellite DNA in nine Sichuan black goat breeds (populations). Acta Veterinaria et Zootechnica Sinica 37, 1124-1129 [in Chinese, English abstract]

Wang J, Wang Y, Deng J (1993) A study on down production of Tibetan goat. Chinese J Rabbit Farming 3, 28-30 [in Chinese, English abstract]

Wang J, Zhong Y, Ouyang X (1994) A comparative study on the ecological characteristics between Tibetan goat of Plateau type and Tibetan goat of Valley type. J Southwest University for Nationalities (Natural Science Edition) 4, $292-298$ [in Chinese, English abstract]

Wang X, Cao HH, Geng SM, Li HB (2004) Genetic Diversity of 10 Indigenous Pig Breeds in China by Using Microsatellite Markers. Asian-Aust J Anim Sci 17, 1219-1222

Zheng PL (1989) Sheep and Goat Breeds in China. Shanghai: Shanghai Science and Technology Press [in Chinese]

Received 30 April 2009, accepted 14 January 2011.

Corresponding author:

Yong Wang

email:wangyong010101@swun.cn

Southwest University for Nationalities, Chengdu 610041, PR China 